\title{
RELAKSASI OTOT PROGRESIF MENINGKATKAN KUALITAS TIDUR PADA LANSIA WANITA
}

\author{
Putu Agus Ariana ${ }^{1}$, G. Nur Widya Putra ${ }^{2}$, Ni Komang Wiliantari ${ }^{3}$ \\ Sekolah Tinggi Ilmu Kesehatan Buleleng ${ }^{1,2,3}$ \\ putuagusariana234@gmail.com ${ }^{1}$
}

\begin{abstract}
ABSTRAK
Tujuan penelitian ini adalah untuk mengetahui efektifitas relaksasi otot progresif untuk meningkatkan kualitas tidur pada lansia yang mengalami insomnia di Desa Unggahan, Kabupaten Buleleng. Metode penelitian ini merupakan penelitian kuantitatif dengan desain penelitian pra eksperimen dengan rancangan pre-post test one group design. Hasil penelitian menunjukkan secara statistik, relaksasi otot progresif efektif untuk meningkatkan kualitas tidur pada lansia wanita dengan nilai $\mathrm{p}=0,000$ atau $p<\alpha(0,05)$. Simpulan, relaksasi otot progresif efektif meningkatkan kualitas tidur pada lansia yang tinggal di rumah.
\end{abstract}

Kata Kunci : Kualitas Tidur, Lansia, Relaksasi Otot Progresif

\section{ABSTRACT}

The purpose of this study was to determine the effectiveness of progressive muscle relaxation to improve sleep quality in the elderly who has insomnia in the Unggahan Village, Buleleng Regency. This research method is a quantitative study with a pre experiment research design with one group design pre-post test design. The results showed statistically, progressive muscle relaxation was effective to improve sleep quality in elderly women with a value of $p=0,000$ or $p<\alpha$ (0.05). Conclusion, progressive muscle relaxation is effective in increasing sleep quality in the elderly who live at home.

Keywords: Sleep Quality, Elderly, Progressive Muscle Relaxation

\section{PENDAHULUAN}

Populasi lansia diprediksi akan terus mengalami peningkatan. Pada tahun 2050 diperkirakan populasi lansia melonjak hingga mencapai tiga kali lipat dari pada tahun tahun sebelumnya (Data dan Informasi profil Kesehatan Indonesia, 2018). Hal ini berdampak pada meningkatnya permasalahan kesehatan yang muncul pada Lansia. Salah satunya adalah gangguan tidur atau insomnia. Gangguan insomnia pada orang dewasa yang lebih tua dikaitkan dengan ketidakpuasan dengan kualitas atau kuantitas tidur dan juga dikaitkan dengan kesulitan tidur, mempertahankan tidur, atau bangun pagi (Cherukuri et al, 2018).

Penelitian tentang teknik relaksasi untuk lansia telah banyak dilakukan. Salah satu penelitian yang telah dilakukan tentang manfaat teknik relaksasi otot progresif yang dilakukan pada pasein yang mengalami hipertensi di Rumah Sakit Umum Imelda pada tahun 2018. Penelitian dilakukan pada 23 orang yang mengalami hipertensi. 
Berdasarkan hasil penelitian, menunjukkan bahwa relaksasi otot progresif berpengaruh pada tekanan darah systole dan diastole pada pasien hipertensi. Rekomendasi yang disampaikan pada penelitian ini adalah diperlukan pengembangan dan penelitian lebih lanjut tentang latihan relaksasi otot progresif (Ziraluo, 2018).

Penelitian lain tentang relaksasi dan edukasi tentang kebersihan tidur juga dilakukan pada sampel wanita yang mengalami menopause. Studi yang dilakukan pada tahun 2018 ini mengambil sampel 161 orang wanita yang mengalami menopause yang mengalami gangguan tidur. Penelitian dilakukan dengan metode penelitian klinis acak dengan kelompok grup dan kontrol. Latihan dilakukan dengan memberikan terapi relaksasi otot progresif yang diberikan berulang-ulang satu kali dalam seminggu selama delapan minggu. Hasil penelitian yang dilakukan menunjukkan hasil yang signifikan pada kelompok perlakuan. Temuan ini merekomendasikan terapi relaksasi otot progresif memiliki manfaat yang baik pada lansia wanita yang mengalami menopause (Duman, Taşhan, 2018).

Kombinasi terapi pada penelitian sebelumnya tentang kualitas tidur yang pernah dilakukan yaitu kombinasi antara senam otak dengan relaksasi benson (beapreasi). Hasil penelitian ini menyatakan bahwa relaksasi terbukti meningkatkan kualitas tidur lansia. Oleh karena itu relaksasi disarankan sebagai salah satu intervensi mandiri keperawatan pada kelompok lansia yang mengalami insomnia (Mustain, 2019).

Pemanfaatan terapi relaksasi otot progresif pada respon fisiologis juga sudah diteliti pada beberapa penelitian yang dilakukan pada tahun 2019. Penelitian yang pertama dilakukan pada 74 orang responden yang mengalami masalah hipertensi pada pasien di Puskesmas. Penelitian yang dilakukan adalah penelitian quasy-experimen preposttest with control group design. Hasil penelitian yang telah dilakukan menunjukkan Adanya perbedaan yang signifikan frekuensi nadi pada kelompok kontrol sebelum dan sesudah intervensi dan adanya perbedaan tekanan darah diastolik pada kelompok intervensi dan kontrol setelah diberikan terapi relaksasi otot progresif ditambah dengan latihan napas dalam (Ekarini et al, 2019).

Penelitian selanjutnya tentang efektifitas teknik Relaksasi Progresif dilakukan pada Lansia yang mengalami Insomnia pada Posyandu Lansia. Penelitian dilakukan pada tahun 2019 dengan jumlah responden adalah 30 orang. Intervensi diberikan pada kelompok kontrol dan kelompok perlakuan. Kuesioner yang digunakan dalam penelitian adalah Insomnia Rating Scale. Hasil penelitian menunjukkan bahwa teknik relaksasi progresif efektif untuk mengurangi Insomnia pada Lansia. Penelitian ini menyarankan untuk dilakukan penelitian lebih lanjut tentang pengaruh tehnik relaksasi progresif tehadap tingkat insomnia usia lanjut dengan desain dan area yang berbeda (Sakitri, Astuti, 2019).

Tekni relaksasi lainnnya untuk intervensi juga ditemukan penelitian yang dilakukan pada lansia yang mengalami gangguan tidur. Pada tahun 2019 dilakukan penelitian dengan sampel 57 orang Lansia yang ada di Iran, yang mengalami gangguan tidur dan dipilih secara acak dengan kelompok perlakuan dan kelompok kontrol. Intervensi dilakukan dengan memberikan relaksasi benson. Intervesi diberikan selama dua kali sehari selama 20 menit. Penelitian dilakukan selama empat minggu. Hasil penelitian menunjukkan peningkatan signifikan dalam kelompok intervensi pada kualitas tidur dan lima subskala termasuk kualitas tidur subjektif, latensi tidur, durasi tidur, dan efisiensi tidur, dan disfungsi siang hari meningkat secara signifikan. Penelitian ini merekomendasikan pada teknik yang efektif dan sederhana dan hemat biaya pada lansia yang mengalami gangguan tidur (Habibollahpour et al, 2019). 
Populasi lansia di Asia Tenggara telah mencapai 8\% atau sekitar 142 juta jiwa. Tahun 2050 diperkirakan populasi lansia melonjak hingga mencapai 3 kali lipat dari pada tahun - tahun sebelumnya. Berdasarkan data diperkirakan pada tahun 2020 jumlah penduduk lansia yaitu berkisar (27,08 juta jiwa ) dan pada tahun 2025 menjadi 33,69 juta jiwa, pada tahun tahun 2030 sebanyak 40,95 juta jiwa (Pusdatin, 2017). Jumlah penduduk lansia di Provinsi Bali adalah sebesar 10,71\% (Data dan Informasi profil Kesehatan Indonesia 2018, 2018). Menurut data prevalensi tahun 2019 yang didapatkan dari Badan Pusat Statistik Kabupaten Buleleng, tentang penduduk lansia yang di golongkan dalam umur 60-75 tahun keatas mencapai 81.7,000 jiwa. Berdasarkan data yang ada di kantor Desa Unggahan di dapatkan jumlah lansia keseluruhan di Desa Unggahan 480 orang.

Angka kejadian gangguan tidur lansia cukup tinggi, berdasarkan data ditemukan bahwa di Indonesia pada usia 65 tahun terdapat 50\% lansia mengalami gangguan tidur. Prevalensi insomnia di Indonesia pada lansia masih tergolong tinggi yaitu sekitar 67\%. Angka ini diperoleh dari populasi yang berusia diatas 65 tahun. Menurut jenis kelamin, didapatkan bahwa insomnia dialami oleh perempuan yaitu sebesar 78,1\% pada usia 60-74 tahun (Mustain, 2019). Insomnia dipengaruhi oleh berbagai faktor. Faktorfaktor tersebut adalah usia yang semakin menua, jenis kelamin perempuan, status perkawinan, kebiasaan merokok, konsumsi minuman berkafein, faktor medis, tekanan psikologis dan kebisingan (Ali et al, 2019).

Berbagai upaya dilakukan untuk mengatasi permasalahan gangguan tidur pada lansia. Terapi bisa dilakukan dengan obat maupun tanpa obat. Terapi yang menggunakan obat tentunya akan memimbulkan efek samping bila digunakan dalam jangka waktu yang lama (Andri et al, 2019). Intervensi pada Insomnia memiliki tujuan utamanya untuk meningkatkan kualitas dan kuantitas tidur bersama dengan gangguan siang hari terkait insomnia. Sebelum memulai terapi untuk insomnia, pengelolaan kondisi komorbiditas perlu dilakukan dapat mengetahui gejala insomnia (Cherukuri et al, 2018). Oleh karena itu, terapi yang direkomendasikan adalah terapi tanpa obat. Salah satu terapi yang digunakan untuk memperbaiki kualitas tidur adalah dengan menggunakan teknik relaksasi otot progresif.

Berdasarkan studi pendahuluan yang dilakukan pada Lansia di Desa Unggahan jumlah lansia yang di wawancara sebanyak 10 orang yang berpedoman pada The Pittsburgh Sleep Quality Index (PSQI) yang dipilih secara acak didapatkan hasil 8 lansia mengalami kualitas tidur buruk dan 2 lansia mengalami kualitas tidur baik (Carole Smyth, 2012). Sebagian besar lansia menggalami gangguan tidur. Itu disebabkan karena memikirkan pekerjaan yang belum tuntas, kesulitan memulai tidur, dan sering terbangun saat malam hari.

Penelitian - penelitian sebelumnya membahas tentang kualitas tidur lansia secara umum. Terapi yang diberikan secara nonfarmakologis masih belum optimal dilakukan, penatalaksanaan pada umumnya dengan menggunakan obat-obatan. Penelitian ini membuktikan terapi relaksasi otot progresif dapat meningkatkan kualitas tidur pada Lansia. Selain itu, penelitian ini membahas lebih spesifik kualitas tidur pada lansia wanita. 


\section{METODE PENELITIAN}

Penelitian ini dilakukan dengan menggunakan pre eksperimental dengan rancangan desain one group pre test post test. Sebelum diberikan intervensi, maka dilakukan pengukuran terlebih dahulu skor kualitas tidur pada lansia sebelum diberikan relaksasi otot progresif. Pengukuran dilakungan dengan menggunkaan kuesioner Pittsburgh Sleep Quality Index (PSQI). Setelah diperoleh nilai pre, tahapan selanjutnya adalah dengan memberikan Relaksasi Otot Progresif pada Lansia. Pemberian intervensi dalam Penelitian ini dilakukan setiap hari 1 kali dengan durasi 30 menit setiap sore selama 2 minggu. Setelah dilakukan selama 2 minggu, kemudian dilakukan pengukuran nilai post dengan menggunakan kuesioner PSQI. Teknik sampling yang digunakan Non probability sampling dengan teknik purposive sampling. Jumlah sampel keseluruhan dalam penelitian ini adalah 32 responden. Data diolah menggunakan program computer. Kaji etik dalam penelitian ini dilakukan oleh Komite Etik Penelitian Kesehatan (KEPK) Sekolah Tinggi Ilmu Kesehatan Buleleng.

\section{HASIL PENELITIAN}

Tabel. 1

Nilai Mean dan Standar Deviasi

Berdasarkan Usia

\begin{tabular}{ccccc}
\hline $\mathrm{N}$ & Mean & SD & Min-Maks & $95 \% \mathrm{CI}$ \\
\hline 32 & 65,27 & 3,56 & $60-74$ & $62,53-66,25$ \\
\hline
\end{tabular}

Sumber: Data Primer (2019)

Berdasarkan tabel 1 menunjukkan hasil analisis didapatkan rata-rata umur Lansia adalah 62,27 tahun (95\% CI: 62,53 - 66,25), dengan standar deviasi 3,56 tahun. Umur termuda adalah 60 tahun dan umur tertua adalah 74 tahun.

Tabel. 2

Distribusi Frekuensi Pendidikan Responden

\begin{tabular}{ccc}
\hline Tingkat pendidikan & Frekuensi (f) & $\begin{array}{c}\text { Persentase } \\
(\%)\end{array}$ \\
\hline SD & 25 & 78,2 \\
SMP & 7 & 21,8 \\
\hline Total & 32 & 100 \\
\hline
\end{tabular}

Sumber: Data Primer (2019)

Berdasarkan Tabel 2 menunjukkan bahwa dari 32 total responden penelitian sebagian besar responden, yaitu 25 orang $(78,2 \%)$ berpendidikan SD.

Tabel. 3

PSQI Responden Sebelum Diberikan

Relaksasi Otot Progresif

\begin{tabular}{ccccccc}
\hline & N & Mean & Min & Maks & SD & 95\%CI \\
\hline Pre test & 32 & 37,85 & 22 & 48 & 6,784 & $35,68-40,02$ \\
\hline \multicolumn{2}{l}{ Sumber: Data Primer (2019) }
\end{tabular}


Berdasarkan tabel 3 menunjukan bahwa rata-rata (mean) skor kualitas tidur responden sebelum diberikan intervensi relaksasi otot progresif 37,85 (95\% CI 35,6840,02), dengan standar deviation 6,784. Skor terendah 22 dan yang tertinggi 48. Dari hasil estimasi interval dapat disimpulkan bahwa 95\% diyakini bahwa rata-rata skor kualitas tidur lansia adalah diantara 35,68 sampai dengan 40,02.

Tabel. 4

PSQI Responden Setelah Diberikan

Relaksasi Otot Progresif

\begin{tabular}{ccccccc}
\hline & N & Mean & Min & Mak & SD & 95\%CI \\
\hline $\begin{array}{c}\text { Post } \\
\text { test }\end{array}$ & 32 & 30,38 & 19 & 43 & 4,683 & $28,88-31,87$ \\
\hline
\end{tabular}

Sumber: Data Primer (2019)

Berdasarkan tabel 4 menunjukan bahwa rata-rata (mean) Skor kualitas tidur responden setelah diberikan intervensi relaksasi otot progresif 30,38 (95\% CI 28,8831,87), dengan standar deviation 4,683, skor terendah 19 dan yang tertinggi 43. Dari hasil estimasi interval dapat disimpulkan bahwa 95\% diyakini bahwa rata-rata skor kualitas tidur lansia setelah diberikan intervensi adalah diantara 28,88 sampai dengan 31,87 .

Tabel. 5

Hasil Analisis Pre dan Post Test

\begin{tabular}{cccc}
\hline Variabel & N & Paired Differences \\
& & Perbedaan (Mean \pm SD) & $P$ \\
\hline $\begin{array}{l}\text { Pre-test \& Post-test } \\
\text { kualitas tidur lansia }\end{array}$ & 32 & $7,475 \pm 5,826$ & 0,000 \\
\hline Sumber: Data Prim & & & \\
\hline
\end{tabular}

Sumber: Data Primer (2019)

Hasil analisis menunjukkan bahwa secara statistik, uji selisih pada skor PSQI pada pre dan posttest diberikan latihan relaksasi otot progresif menunjukkan nilai yang sognifikan. Berdasarkan tabel 5 di atas dengan menggunakan program komputer, menunjukan bahwa nilai $P$-value $0,000(P \leq 0,05)$. Secara statistik, ini menunjukkan terdapat perbedaan kualitas tidur sebelum dan sesudah diberikan intervensi relaksasi otot progresif.

\section{PEMBAHASAN}

\section{Karakteristik Responden}

Kelompok masyarakat yang mengalami insomnia terjadi pada kelompok yang berusia diatas 60 tahun. Ini tergolong ke dalam lansia. Semakin meningkat usia seseorang, maka risiko mengalami gangguan kesehatan semakin meningkat. Hasil penelitian pada estimasi interval dapat disimpulkan bahwa $95 \%$ diyakini bahwa rata-rata umur lansia adalah diantara 62,53 sampai dengan 66,25 tahun, dengan rata-rata umur lansia adalah 62, 27 tahun. Menurut peneliti umur responden yang tergolong lansia akan sering mengalami gangguan kebutuhan tidur, hal ini terjadi karena proses penuaan yang sangat mempengaruhi kualitas tidur lansia. 
Pola tidur yang normal mulai berubah sesuai bertambahnya usia, akibat reduksi saraf yang mempengaruhi gelombang tidur atau oleh karena defisit sistem saraf pusat yang menyebabkan berkurangnya reaksi terhadap alarm ekstrinsik dan disfungsi irama tubuh serta berkurangnya pengeluaran melatonin. Kondisi umur lansia yang semakin meningkat membuat lansia mengalami penurunan fungsi sel saraf otak yang menyebabkan reduksi kerja saraf yang berpengaruh pada penurunan perasaan yang merangsang untuk tidur. Hal ini secara fisiologis dapat menyebabkan kualitas dan kuantitas tidur lansia menurun (Prasetyo et al, 2020).

Semua lansia yang dijadikan sampel dalam penelitian ini adalah lansia dengan jenis kelamin perempuan. Menurut peneliti jenis kelamin perempuan memang sangat dominan untuk mengalami gangguan tidur khususnya kepuasan tidur. Aktifitas perempuan lebih tinggi dibandingkan dengan laki-laki. Hal ini akan berdampak pada kualitas tidur disebabkan karena perempuan bangun pada dini hari untuk membuatkan makanan untuk anak-anaknya dan juga suaminya, dan perempuan juga sering mengantuk saat melakukan aktifitas di siang hari. Hasil penelitian ini sejalan dengan penelitian yang dilakukan oleh Hartono pada tahun 2019. Penelitian yang telah dilakukan mengungkapkan bahwa Insomnia terjadi pada lansia yang berusia diatas 60 tahun. Hal ini disebabkan karena lansia mengalami perubahan-perubahan secara fisik dan neurologis pada tubuhnya. Jenis kelamin perempuan lebih banyak yang mengalami Insomnia (Februanti et al, 2019).

Selain usia, karakteristik pendidikan juga dilihat dalam penelitian ini. Pendidikan responden sebagian besar memiliki tingkat pendidikan SD sebanyak 25 orang $(78,2 \%)$ dan SMP 7 orang $(21,8 \%)$. Berdasarkan pendidikan, lansia di Desa Unggahan pendidikannya dapat dikategorikan rendah. Menurut peneliti, rendahnya tingkat pendidikan seseorang akan lebih banyak tingkat stresornya. Stressor yang tinggi dapat menambah beban pikiran, sehingga dapat mengganggu kualitas tidur seseorang. Peneliti berasumsi bahwa semakin tinggi pendidikan seseorang maka semakin meningkat pula kualitas tidurnya, sebaliknya semakin rendah pendidikan seseorang maka semakin menurun pula kualitas tidurnya.

Penelitian yang dilakukan tidak sejalan dengan penelitian yang dilakukan sebelumnya. Pendidikan yang rendah tidak berkorelasi secara langsung terhadap kualitas tidur. Namun, pendidikan yang rendah cenderung berdampak pada kecemasan Lansia. Kecemasan inilah yang akan mengakibatkan kesulitan untuk tidur. Hasil analisis menunjukan adanya hubungan antara tingkat kecemasan dan kualitas tidur lansia (Dariah, Okatiranti, 2015).

Penelitian ini sejalan dengan penelitian lanjutan yang dilakukan oleh Sakiri dan Astuti pada tahun 2019. Hasil penelitiannya menunjukkan bahwa lansia yang berpendidikan rendah menderita insomnia lebih tinggi bila dibandingkan dengan yang berpendidikan lebih tinggi (Sakitri, Astuti, 2019).

\section{Kualitas Tidur Lansia Sebelum Diberikan Intervensi Relaksasi Otot Progresif}

Sebelum intervensi diberikan pada lansia, peneliti melakukan diskusi terlebih dahulu dengan lansia yang menjadi responden. Diskusi dilakukan untuk menyamakan persepsi lansia tentang intervensi yang diberikan. Lansia yang menjadi responden harus kooperatif dan mengikuti seluruh intervensi yang diberikan.

Berdasasarkan penelitian yang dilakukan, diperoleh hasil pengukuran kualitas tidur sebelum diberikan intervensi relaksasi otot progresif di Desa Unggahan Kecamatan Seririt Kabupaten Buleleng menunjukkan bahwa rata-rata kualitas tidur 
responden sebelum diberikan intervensi relaksasi otot progresif adalah 37,85 dengan nilai minimum 22 dan nilai maksimum 48. Menurut asumsi peneliti, kualitas tidur lansia di Desa Unggahan disebabkan aktivitas fisik dan kurangnya relaksasi. Hal ini dilihat dari aktivitas lansia yang masih produktif, melakukan aktifitas di kebun dan juga lansia didesa unggahan dominan bekerja sebagai petani maka waktu yang mereka punya hanya untuk mengarus ladang. Berdasarkan teori, banyaknya aktivitas yang dilakukan tentu menyebabkan masalah fisik dan psikologis. Hasil penelitian ini sejalan dengan penelitian tentang penyakit fisik dan lingkungan yang mempengaruhi kejadian insomnia pada lansia (Hartono et al, 2019).

Masalah psikologis juga terjadi pada lansia yang mengalami insomnia. Gejala yang muncul adalah kecemasan pada lansia. Sejalan dengan penelitian tentang faktorfaktor yang mempengaruhi tidur salah satunya adalah kecemasan. Hasil penelitian yang telah dilakukan menunjukkan bahwa terdapat hubungan antara kecemasan dengan kualitas tidur pada pasien insomnia. Gaya hidup yang dimaksud adalah rutinitas yang sering dilakukan oleh seseorang dapat mempengaruhi pola tidur. Kepuasan kualitas tidur seseorang dipengaruhi oleh irama sirkadian yaitu dengan siklus tidur 24 jam siang sampai malam.

\section{Kualitas Tidur Lansia Setelah Diberikan Intervensi Relaksasi Otot Progresif}

Pengukuran kualitas tidur responden dilakukan setelah diberikan intervensi relaksasi otot progresif selama 2 minggu, dan setiap minggunya dilakukan 7 kali Hasil penilaian kualitas tidur setelah dilakukan intervensi relaksasi otot progresif didapatkan bahwa rata-rata kualitas tidur responden di Desa Unggahan Kabupaten Buleleng setelah diberikan intervensi relaksasi otot progresif adalah 30,38 dengan nilai minimum 19 dan nilai maksimum 43. Menurut peneliti, pemberian terapi relaksasi otot progresif dapat meningkatkan kualitas tidur lansia. Hal ini dikarenakan relaksasi otot progresif merupakan teknik relaksasi otot yang tidak memerlukan sugesti, imajinasi tetapi hanya memusatkan perhatian pada suatu aktivitas otot dengan mengidentifikasi otot yang dulu tegang menjadi rileks dan relaksasi otot progresif juga mengkombinasikan latihan napas dalam. Semakin fokus seseorang dalam melakukan gerakan relaksasi otot progresif akan menyebabkan penurunan ketegangan otot menjadi rileks, sehingga peneliti berasumsi bahwa pemberian latihan relaksasi otot progresif efektif untuk meningkatkan kualitas tidur lansia.

Sejalan dengan Penelitian yang dilakukan oleh Hidayat, Hanifah didapatkan nilai p-value 0,000 sehingga dapat disimpulkan terdapat pengaruh relaksasi otot progresif terhadap pola tidur pada lansia di Dusun Daleman Desa Poreh Kecamatan Lenteng (Hidayat, Hanifah, 2019).

\section{Relaksasi Otot Progresif Meningkatkan Kualitas Tidur pada Lansia di Desa Unggahan Kabupaten Buleleng}

Hasil uji statistik didapatkan bahwa $P$-Value $0,000(P<0,05)$ terdapat pengaruh relaksasi otot progresif terhadap kualitas tidur pada lansia di Desa Unggahan Kabupaten Buleleng. Dari hasil penelitian tersebut diperoleh bahwa relaksasi otot progresif efektif untuk meningkatkan kualitas tidur pada lansia yang mengalami Insomnia, sesudah diberikan intervensi. Peningkatan kualitas tidur ini diukur dengan melihat skor posttest PSQI. Dari hasil tersebut dapat dilihat bahwa penurunan skor $P S Q I$ menunjukkan peningkatan pada kualitas tidur lansia. 
Berdasarkan hasil tersebut, juga dibuktikan oleh penelitian dengan judul "pengaruh pelaksanaan relaksasi otot progresif terhadap kualitas tidur pada lansia hipertensi di Puskesmas Tumpang Kecamatan Talun Kabupaten Blitar". Hasil uji statistik didapatkan $P$-Value 0,001 disimpulkan ada pengaruh pelaksanaan relaksasi otot progresif terhadap kualitas tidur pada lansia hipertensi di Puskesmas Tumpang Kecamatan Talun Kabupaten Blitar (Sunaringtyas, Kusdiantoro \& Lendra, 2018).

Dari pembahasan tersebut, dapat dikaitkan dengan teori dan penelitian sebelumnya, bahwa kualitas tidur pada lansia dapat ditingkatkan dengan melakukan pemberian terapi relaksasi otot progresif. Lansia yang melakukan relaksasi otot progresif akan terbangun pada kondisi yang lebih segar dan lebih rileks dari sebelumnya. Kondisi ini memperbaiki irama sirkadian pada lansia. Hasil penelitian yang sejalan juga menunjukkan bila irama sirkadian pada lansia tidak diperbaiki, maka akan lebih berisiko untuk mengalami kebiasaan tidur yang buruk. Hal ini ditunjukkan dengan jam tidur yang tidak teratur pada lansia (Danirmala, Ariani, 2019).

Hal yang sangat penting untuk diperhatikan bagi lansia adalah konsistensi dalam melakukan relaksasi otot progresif. Relaksasi tentu tidak akan bisa memperoleh hasil maksimal bila tidak dilakukan dengan teratur dan konsisten. Hasil penelitian yang dilakukan sebelumnya menjadikan konsistensi sebagai faktor yang menentukan keberhasilan intervensi ini. Konsistensi dari tehnik relaksasi progresif dalam penelitian yang dilakukan membuktikan bahwa tehnik relaksasi progresif mempunyai hasil yang signifikan untuk menurunkan insomnia pada lansia. Beberapa faktor yang mempengaruhi keberhasilan tehnik relaksasi progresif dalam menyembuhkan insomnia yaitu konsistensi melakukan tehnik relaksasi progresif, kondisi lansia yang sehat serta lingkungan yang tenang saat melakukan tehnik relaksasi progresif. Dari hasil penelitian terjadi penurunan jumlah responden yang mengalami insomnia (Sakitri, Astuti, 2019).

Dengan demikian, sebagai rekomendasi yang diberikan pada lansia adalah perilaku umum terutama saran tentang praktik tidur yang sehat seperti mengurangi waktu di tempat tidur, bangun pada waktu yang sama setiap pagi terlepas dari hari dalam seminggu dan jumlah tidur, tidur hanya ketika mengantuk, tidak tinggal di tidur kecuali tidur, dan untuk berlatih teknik relaksasi dan fokus (Cherukuri et al, 2018).

\section{SIMPULAN}

Karakteristik responden dalam penelitian ini yaitu lansia wanita. Berdasarkan pendidikan, yang terbanyak adalah lansia dengan pendidikan Sekolah Dasar. Terdapat perbedaan Skor PSQI sebelum dilakukan intervensi dan setelah dilakukan intervensi. Pada nilai pre dan post dapat dibandingkan bahwa terjadi peningkatan kualitas tidur pada lansia. Hal ini menunjukkan bahwa relaksasi otot progresif efektif untuk meningkatkan kualitas tidur pada lansia. Dengan demikian, relaksasi otot progresif sangat potensial diterapkan untuk meningkatkan kualitas perawatan pada lansia.

\section{SARAN}

\section{Bagi Pelayanan}

Puskesmas sebagai tempat pelayanan perlu mempertimbangkan untuk menerapkan relaksasi otot progresif. Dalam penerapannya, perlu dipertimbangan untuk pembuatan media promosi berupa leaflet dengan materi relaksasi otot progresif untuk meningkatkan kualitas tidur pada lansia. 


\section{Bagi Keilmuan}

Hasil penelitian ini diharapkan dapat dijadikan sumber informasi bagi keperawatan terutama dalam keperawatan gerontik dan keperawatan komunitas. Sehingga mutu pelayanan keperawatan semakin meningkat.

\section{Bagi Penelitian Selanjutnya}

Penelitian lanjutkan untuk menyempurnakan penelitian diperlukan dengan menambahkan jumlah sampel dan mebandingkan hasil penelitian terhadap lansia lakilaki. selain itu, modifikasi teknik relaksasi otot progresif dengan menambahkan teknik yang lain juga direkomendasikan dalam penelitian ini.

\section{DAFTAR PUSTAKA}

Ali, T., Belete, H., Awoke, T., Zewde, F., Derajew, H., Yimer, S., \& Menberu, M. (2019). Insomnia among Town Residents in Ethiopia: A Community-Based Cross-Sectional Survey. Sleep Disorders, 2019, 1-7. https://doi.org/10.1155/2019/6306942

Andri, J., Karmila, R., Padila, P., Harsismanto, J., \& Sartika, A. (2019). Pengaruh Terapi Aktivitas Senam Ergonomis terhadap Peningkatan Kemampuan Fungsional Lansia. Journal of Telenursing, 1(2), 304-313. https://doi.org/https://doi.org/10.31539/joting.v1i2.933

Carole Smyth. (2012). The Pittsburgh Sleep Quality Index ( PSQI ) The Pittsburgh Sleep Quality Index ( PSQI ). New York. https://doi.org/10.1007/978-1-44199893-4

Cherukuri, C. M., Kaplish, N., Malepati, D. C., Khawaja, I. S., Bhatia, S. K., \& Bhatia, S. C. (2018). Insomnia in older adults. Psychiatric Annals, 48(6), 279-286. https://doi.org/10.3928/00485713-20180514-01

Danirmala, D., \& Ariani, P. (2019). Angka Kejadian Insomnia pada Lansia di Panti Tresna Werdha Wana Seraya Denpasar. E-Jurnal Medika, 8(1), 27-32

Dariah, E. D., \& Okatiranti, O. (2015). Hubungan Kecemasan dengan Kualitas Tidur Lansia di Posbindu Anyelir Kecamatan Cisarua Kabupaten Bandung Barat. Jurnal Ilmu Keperawatan

Duman, M., \& Taşhan, S. T. (2018). The effect of Sleep Hygiene Education and Relaxation Exercises on Insomnia among Postmenopausal Women: A Randomized Clinical Trial. International Journal of Nursing Practice, 24(4), 1-8. https://doi.org/10.1111/ijn.12650

Ekarini, N. L. P., Heryati, H., \& Maryam, R. S. (2019). Pengaruh Terapi Relaksasi Otot Progresif terhadap Respon Fisiologis Pasien Hipertensi. Jurnal Perawat Indonesia, 10(1), 47. https://doi.org/10.26630/jk.v10i1.1139

Februanti, S., Hartono, D., \& Cahyati, A. (2019). Penyakit Fisik dan Lingkungan terhadap Insomnia bagi Lanjut Usia. Quality: Jurnal Kesehatan, 13(1), 1-4. https://doi.org/10.36082/qjk.v13i1.51

Habibollahpour, M., Ranjkesh, F., Motalebi, S. A., \& Mohammadi, F. (2019). The Impact of Benson's Relaxation Technique on the Quality of Sleep in the Elderly. Topics in Geriatric Rehabilitation, 35(1), 88-94. https://doi.org/10.1097/TGR.0000000000000204

Hartono, D., Somantri, I., \& Februanti, S. (2019). Hipnosis Lima Jari dengan Pendekatan Spiritual Menurunkan Insomnia pada Lansia. Jurnal Kesehatan, 10(2), 187-192. https://doi.org/10.26630/JK.V10I2.1218 
Hidayat, S., \& Hanifah, M. (2019). Pengaruh Relaksasi Otot Progresif terhadap Pola Tidur pada Lansia di Dusun Daleman Desa PorehKecamatan Lenteng. Jurnal Ilmiah Keperawatan Stikes Hang Tuah Surbaya. https://doi.org/10.30643/jiksht.v13i1.17

Kemenkes RI. (2018). Data dan Informasi Profil Kesehatan Indonesia 2018

Mustain, D. (2019). Pengaruh Terapi Beapreasi (Kombinasi Senam Otak dengan Relaksasi Benson) terhadap Kualitas Tidur, 3(1), 1-8

Prasetyo, W., Nancye, P. M., \& Sitorus, R. P. (2020). Pengaruh Relaksasi Benson terhadap Tingkat Insomnia pada Lansia di Griya Usia Lanjut St . Yosef Surabaya. Jurnal Keperawatan Stikes William Booth, 8(2), 34-42

Sakitri, G., \& Astuti, R. K. (2019). Efektifitas Teknik Relaksasi Progresif untuk Mengurangi Insomnia pada Usia Lanjut. Avicenna Journal of Health Research, 2(2), 34-45. https://doi.org/10.1017/CBO9781107415324.004

Sunaringtyas, D. Z., Kusdiantoro, L. W. F. (2018). Pengaruh Pelaksanaan Relaksasi Otot Progresif terhadap Kualitas Tidur pada Lansia Hipertensi di Puskesmas Tumpang Kecamatan Talun Kabupaten Blitar. Jurnal Keperawatan Respati Yogyakarta

Ziraluo, H. D. A. A. W. (2018). Pengaruh Teknik Relaksasi Otot Progresif terhadap Penurunan Tekanan Darah pada Pasien Hipertensi di Rsu Imelda. Jurnal Keperawatan Priority, 1(2), 96-104 